\title{
Turning the corner on intubation: fibrescope-assisted videolaryngoscopy
}

\author{
Stephen Mannion, FCARCSI · Brian D. O'Donnell, FCARCSI
}

Received: 14 July 2009/Accepted: 22 July 2009/Published online: 5 August 2009

(C) Canadian Anesthesiologists' Society 2009

\section{To the Editor,}

The Glidescope ${ }^{\circledR}$ (Verathon Medical (UK) Ltd., Aston Sandford, United Kingdom) is a videolaryngoscope, which improves the Cormack and Lehane (CL) grade of laryngoscopy due to its $60^{\circ}$ viewing orientation. ${ }^{1}$ Notwithstanding this ability to "see around corners", it is impossible to intubate the trachea in $4 \%$ of patients using the Glidescope ${ }^{\circledR}$, despite a satisfactory glottic view and the use of a preformed stylet or flexible introducer. ${ }^{2}$ Reasons for failure include the inability to maneuver the endotracheal tube (ETT) into the glottis or the ETT abutting the anterior portion of the larynx when using the stylet.

An intubating fibreoptic bronchoscope (fibrescope) can be dynamically manipulated in multiple directions potentially overcoming the aforementioned limitations. Previous reports of combining a Glidescope ${ }^{\circledR}$ and fibrescope were focused either on the Glidescope ${ }^{\circledR}$ as an oropharyngeal camera aiding fibreoptic intubation or on a single case performed by one operator with limited detail regarding the technique. ${ }^{3,4} \mathrm{We}$ present our experience of fibrescopeassisted videolaryngoscopy (FAV) in both anticipated and unanticipated difficult airways, in multiple patients, and with multiple operators.

The FAV technique is performed following induction of general anesthesia and involves two components. First, the Glidescope ${ }^{\circledR}$ is inserted to obtain the best possible view of the glottis. Second, the fibrescope (with ETT pre-mounted) is introduced into the pharynx by an assistant until seen on the Glidescope ${ }^{\circledR}$ screen. Using the Glidescope ${ }^{\circledR}$ image for guidance, the anesthesiologist manipulates the fibrescope to direct it into the larynx and then the trachea (Fig. 1). The

S. Mannion, FCARCSI $(\bowtie) \cdot$ B. D. O’Donnell, FCARCSI South Infirmary-Victoria University Hospital, Cork, Ireland e-mail: mannionstephen@gmail.com

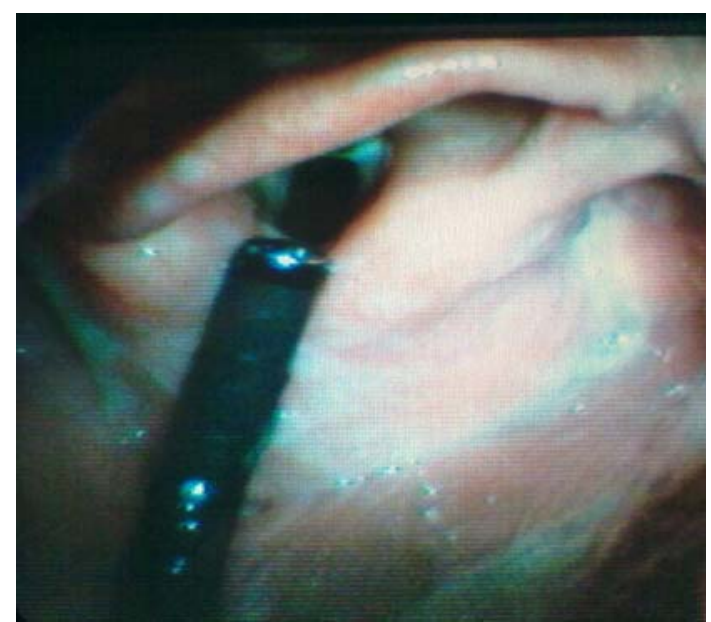

Fig. 1 Using the Glidescope ${ }^{\circledR}$ screen image, the fibrescope tip is placed at the glottic aperture but requires manipulation caudally and posteriorly to enter the trachea

ETT is next advanced over the fibrescope, thus securing the airway.

The FAV technique has been used successfully in 25 patients, including 12 anticipated and 13 unanticipated difficult airways, where intubation of the trachea was impossible with the Glidescope ${ }^{\circledR}$ alone. The cases involved six independent anesthesiologists and one head and neck surgeon. The details of four cases are summarized in Table 1. Since its introduction, there have been no failures using the FAV technique.

For CL grades 1 and 2 views, the fibrescope functions as a dynamic laryngeal and tracheal introducer. In patients with CL grades 3 and 4 views, the Glidescope ${ }^{\circledR}$ optimizes the position of the tongue and pharyngeal structures facilitating rapid placement of the fibrescope followed by conventional fibreoptic confirmation of tracheal intubation. 
Table 1 Cases of successful intubation using the fibrescope-assisted videolaryngoscopy (FAV) technique

\begin{tabular}{lllllll}
\hline Case no. & $\begin{array}{l}\text { Age } \\
\text { (years) }\end{array}$ & Gender & Surgery & $\begin{array}{l}\text { Difficult airway } \\
\text { anticipated (yes/no) }\end{array}$ & $\begin{array}{l}\text { Reason for failure of } \\
\text { videolaryngoscopy }\end{array}$ & Comment \\
\hline Patient 1 & 74 & Male & Inguinal hernia repair & No & Grade 3 view & $\begin{array}{c}\text { Mallampati 2, grade 4 view } \\
\text { on direct laryngoscopy }\end{array}$ \\
Patient 2 & 51 & Female & Pectoral flap revision & Yes & $\begin{array}{c}\text { Grade 4 view } \\
\text { Previous head and neck } \\
\text { cancer with radiotherapy }\end{array}$ \\
Patient 3 & 36 & Male & Nasal surgery & No & Ynable to intubate with stylet & $\begin{array}{c}\text { Obese, Mallampati 1, Grade } \\
\text { 3 on direct laryngoscopy }\end{array}$ \\
Patient 4 & 64 & Male & Laryngoscopy & Yes & $\begin{array}{c}\text { Unable to intubate with stylet } \\
\text { despite grade 2 view }\end{array}$ & $\begin{array}{r}\text { Previous laryngeal tumour } \\
\text { with radiotherapy }\end{array}$ \\
\hline
\end{tabular}

The "macroscopic" videolaryngoscopic image helps to avoid the "tunnel view" or detached environment involved in peering down the fibrescope.

Anesthesiologists are aware that deficiencies exist with most airway techniques. As already discussed, the FAV technique has assisted us in overcoming many of these shortcomings. In practical terms, convenience and availability of a fibrescope is a prerequisite for this technique. We recommend that (1) a portable battery-operated fibreoptic bronchoscope be kept with the theatre block's difficult airway trolley to ensure immediate access, and (2) the difficult airway trolley be present and prepared in the anesthesia induction area if a difficult airway is anticipated. Obviously, further scientific evaluation of the FAV technique is required; however, it is presented here as a "clinical tip" that may prove beneficial in daily practice.

Funding No specific funding was required or received as the study was based on clinical observation. Both authors practice in a national, health-funded hospital where all equipment is provided by the hospital for routine anesthesia care.

Conflicts of interest None declared.

\section{References}

1. Sun DA, Warriner CB, Parsons DG, Klein R, Umedaly HS, Moult $M$. The GlideScope Video Laryngoscope: randomized clinical trial in 200 patients. Br J Anaesth 2005; 94: 381-4.

2. Cooper RM, Pacey JA, Bishop MJ, McCluskey SA. Early clinical experience with a new videolaryngoscope (GlideScope) in 728 patients. Can J Anesth 2005; 52: 191-8.

3. Doyle DJ. GlideScope-assisted fiberoptic intubation: a new airway teaching method. Anesthesiology 2004; 101: 1252.

4. Moore MS, Wong AB. GlideScope intubation assisted by fiberoptic scope. Anesthesiology 2007; 106: 885. 